\title{
CUSTOMER RELATIONSHIP MANAGEMENT, FRAMING EFFECT, TINGKAT KEPUASAN TERHADAP TINGKAT KEPERCAYAAN DAN LOYALITAS NASABAH DALAM PENGGUNAAN LAYANAN MOBILE BANKING PADA NASABAH BANK BRI CABANG RENON
}

\author{
Desak Made Febri Purnama Sari, G.A Putu Anggun Darmaningsih* \\ Universitas Pendidikan Nasional Denpasar (Undiknas) Denpasar \\ *e-mail: dskfebripurnama@undiknas.ac.id
}

DiPublikasi: 01/01/2021

http://dx.doi.org/10.22225/kr.11.2.1154.190-196

\begin{abstract}
In this digital era with the rapid development of technology, it has been able to provide benefits for human life. One of them is the use of technology in the banking world that is manifested in a Mobile Banking application. The rapid development of technology must also be balanced with the use and proper understanding. This research will discuss about how banks provide satisfying services to their customers, then how to provide technology-based services that can be received, understood and utilized appropriately by customers. If seen from the fact that the writer met in the community which incidentally is a customer in a bank, then the writer can conclude that there are still customers who experience dissatisfaction and limited knowledge of the Mobile Banking services provided by the bank. Therefore this research was conducted to find out how Customer Relationship Management, Framing Effect, level of satisfaction can affect the Level of Customer Trust and Loyalty in the use of Mobile Banking services.
\end{abstract}

Keywords: Mobile Banking, Customer Relationship Management, Framing Effect, Satisfaction, Trust, Loyalty

Abstrak

Di era yang serba digital dengan perkembangan teknologinya yang sangat pesat ini, telah mampu memberikan manfaat bagi kehidupan manusia. Salah satunya adalah pemanfaatan teknologi dalam dunia perbankan yang terwujud dalam sebuah aplikasi Mobile Banking. Perkembangan teknologi yang pesat harus diimbangi pula dengan penggunaan dan pemahaman yang tepat. Dalam penelitian ini akan dibahas tentang bagaimana perbankan memberikan layanan yang memuaskan kepada nasabahnya, kemudian bagaimana memberikan layanan berbasis teknologi yang dapat diterima, dipahami dan dimanfaatkan secara tepat oleh nasabah? Jika dilihat dari kenyataan yang penulis temui di dalam masyarakat yang notabenanya adalah nasabah dalam suatu bank, maka penulis dapat menyimpulkan bahwa masih terdapat nasabah yang mengalami ketidak puasan maupun keterbatasan pengetahuan terhadap layanan Mobile Banking yang diberikan oleh pihak bank. Maka dari itu penelitian ini dilakukan untuk mengetahui bagaimana Customer Relationship Management, Framing Effect, Tingkat Kepuasan dapat berpengaruh terhadap Tingkat Kepercayaan dan Loyalitas Nasabah dalam penggunaan layanan Mobile Banking.

Kata Kunci : Mobile Banking, Customer Relationship Management, Framing Effect, Kepuasan, Kepercayaan, Loyalitas.

\section{PENDAHULUAN}

Perkembangan teknologi dan informasi melaju sangat pesat, dan bahkan sudah sangat mempengaruhi kehidupan manusia di era yang serba digital ini. Banyak kegiatan dan aktivitas manusia ditunjang dan dibantu oleh perkembangan teknologi. Salah satunya adalah perkembangan teknologi dalam dunia perbankan yaitu berupa layanan aplikasi Mobile Banking. Layanan Mobile Banking ini akan memberikan kemudahan bagi para nasabahnya dalam melakukan transaksi finansialnya, sehingga dapat dilakukan secara lebih efisien dan juga efektif terhadap waktu dan juga tempat, karena dapat dilakukan kapan saja dan dimana saja tanpa harus datang langsung ke bank. Cukup dengan memasang aplikasi Mobile Banking pada smarphonenya maka nasabah sudah dapat menikmati layanan perbankan yang berbasis digital tersebut. Bank BRI adalah salah satu bank yang juga turut memberikan layanan kepada nasabahnya dengan pemanfaatan tenologi. Layanan berbasis teknologi yang diberikan oleh bank BRI sebelumnya berupa Aplikasi BRI Mobile Banking. Aplikasi BRI Mobile Banking ini memberikan layanan hanya sebatas internet banking, call BRI, info BRI, dan TBank BRI. Yang saat ini telah berevolusi menjadi aplikasi BRImo BRI yang menyediakan layanan yang jauh lebih lengkap 
dibandingkan aplikasi sebelumnya. Yang dimana dalam aplikasi BRImo BRI ini memungkinkan nasabah untuk melakukan pembukaan rekening tabungan baru, pengecekan mutasi rekening yang sebelumnya hanya dalam 5 bulan terakhir kini dapat dicek dalam 12 bulan terakhir, dan memungkinkan nasabah untuk melakukan top-up saldo.

Kehadiran teknologi dihadirkan untuk dapat membantu memudahkan pemberian layanan pemanfaatannya ternyata belum maksimal. Karena masih ada nasabah yang melakukan komplain atas pelayanan berbasis teknologi yang mereka terima, seperti sering terjadinya gangguan koneksi saat bertransaksi melalui Mobile Banking, pada saat melakukan transaksi dinyatakan gagal namun saldo sudah terpotong dan masih banyak kasus lainnya. Dalam hal ini perlu adanya pengoptimalan upayaupaya yang harus dilakukan oleh pihak bank. Dengan cara mengkaji dan mempelajari lebih dalam lagi apa saja kebutuhan dari para nasabahnya melalui strategi Customer Relationship Management yang terdapat dalam perusahaan, yang dimana di dalam strategi ini bermaksud untuk memberikan layanan yang melibatkan antara manuasia, teknologi dan juga proses yang terdapa di dalamnya. Jadi di dalam suatu aplikasi Mobile Banking wajib adanya keterlibatan manusia sebagai pengguna teknologi yang kemudian menjalankan proses pengoperasian dari teknologi tersebut, sehingga tekonologi yang tersedia dapat difungsikan sebagaimana mestinya, dan layanan terhadap nasabah dapat dimaksimalkan. Selain adanya strategi CRM, perlu adanya pengenalan produk kepada nasabah maupun calon nasabah. Karena masih banyak masyarakat atau nasabah dalam dunia perbankan belum tersentuh atau masih awam dengan cara penggunaan teknologi dan juga manfaatannya, oleh sebab itu perlu dilakukan pengenalan terkait teknologi serta aplikasi-aplikasi yang berbasis teknologi. Pengenalan teknologi atau aplikasi yang berbau teknologi seperti aplikasi

\section{TINJAUAN PUSTAKA}

\section{Customer Relationship Management}

Customer Relationship Management berkaitan dengan teknologi, atau merupakan strategi yang diupayakan oleh suatu perusahaan atau instansi untuk memberikan layanan kepada pelanggannya dengan cara pemanfaatan teknologi yang dijalankan melalui proses kepada nasabah, namun semakin canggih teknologi

BRImo, dapat dilakukan dengan penyebaran informasi yang variatif agar dapat diterima oleh masyarakat luas. Di dalam ilmu ekonomi khususnya ilmu Akuntansi Keperilakuan, penyediaan satu informasi yang sama namun dengan cara penyediaan informasi yang berda-beda disebut dengan Framing Effect. Contoh penyediaan informasi yang variatif dapat berupa penyebaran informasi secara langsung kepada nasabah yang berkunjung ke bank, melalui media cetak seperti baliho, spanduk, brosur dan lain sebagainya, kemudian dapat melalui pemanfaatan media sosial dan lain-lain. Masih sering terjadinya gangguan pelayanan dengan pemanfaatan serta kurangnya pemahaman dalam penggunaan teknologi dari pengguna, maka dapat mempengaruhi Tingkat Kepuasan dan Loyalitas nasabah khusunya dalam penggunaan layanan Mobile Banking, seperti masih sering adanya masalah dan keterbatasan layanan. Oleh sebab itu perlu diterapkan penggunaan strategi dan pendekatan terhadap nasabah yang tepat agar nasabah dapat memperoleh tingkat kepuasan yang maksimal terhadap layanan alikasi Mobile Banking, semakin tercapainya harapan nasabah maka nasabah akan merasa semakin puas. Tentunya kepuasan nasabah akan mempengaruhi Tingkat Kepercayaan yang akan diberikan nasabah terhadap pihak bank. Setelah nasabah memiliki kepercayaan terhadap layanan aplikasi BRImo maka loyalitas nasabah dalam penggunaannya akan semakin tinggi. Oleh sebab itu perlu diterapkan penggunaan strategi dan pendekatan terhadap nasabah yang tepat agar nasabah dapat memperoleh tingkat kepuasan yang maksimal terhadap layanan alikasi Mobile Banking, semakin tercapainya harapan nasabah maka nasabah akan merasa semakin puas. Tentunya kepuasan nasabah akan mempengaruhi Tingkat Kepercayaan yang akan diberikan nasabah terhadap pihak bank. Setelah nasabah memiliki kepercayaan terhadap layanan aplikasi BRImo maka loyalitas nasabah dalam penggunaannya akan semakin tinggi.

oleh manusia. Menurut (Marakas, George M. dan O'brien, 2017) CRM merupakan suatu sistem dalam perusahaan yang memanfaatkan teknologi informasi untuk memberikan pelayanan terhadap pelanggan dalam pemasaran, penjualan, maupun jasa dengan prosesproses yang lebih otomatis dan terintegrasi. Sedangkan (Sirait, 2018) mengutarakan tiga indikator yang terdapat di dalam CRM diantaranya sehagai herikut. Continuity 
Marketing Programs yaiutu merupakan pemberian sebuah reward atau feedback kepada pelanggan melalui pemberian kartu pelanggan atau no id pelanggan. Yang dimana pelanggan akan memperoleh diskon, poin, ataupun pembelian produk lain melalui kepemilikan kartu ataupun no id pelanggan yang telah diberikan, One to One Marketing Programs yaitu Melakukan suatu identifikasi terhadap preferensi maupun kebutuhan pelanggan dengan cara melakukan pendekatan kepada pelanggan melalui penggunaan aplikasi ataupun internet, guna memberikan produk atau jasa yang sesuai dengan kebutuhan dari pelanggan, Partnering Programs Pemberian layanan kepada pelanggan dengan cara melakukan suatu mitra atau kerjasama dengan pihak lain, guna memberikan pelayanan dan kebutuhan terhadap pelanggan secara lebih optimal dan memuaskan.

\section{Framing Effect}

Di dalam ilmu akuntansi khususnya akuntansi keperilakuan, Framing Effect merupakan suatu teori tentang bagaimana pesan media massa memperoleh sudut pandang, perspektif, ataupun bias. Kemudain Framing Effect juga merupakan suatu keputusan seseorang yang dipengaruhi oleh cara penyajian informansinya (Kahneman, D., \& Tversky, 1979). Sedangkan menurut sebuah jurnal dari (Amril Arifin \& Indra Wijaya Kusuma) menyatakan bahwa Framing Effect adalah suatu respon terhadap suatu permasalahan yang sama dengan respon yang berbeda-beda oleh si pembuat keputusan. Sedangkan menurut (Robbins SP, 2011) menyatakan bahwa Framing Effect mengabaikan aspek lain namun memilih satu atau lebih subjek dan juga pengelolaan makna melalui Bahasa yang disampaikan. Di dalam buku (Sari, 2018) mengutarakan beberapa indikator Framing Effect, yaitu sebagai berikut: Prospect Theory yaitu Dikemukakan oleh (Kahneman, D., \& Tversky, 1979) yang menyatakan bahwa jika informasi tentang suatu masalah dinyatakan dalam suatu gain domain atau positive frame maka pembuat keputusan akan memilih pilihan yang tidak berisiko (risk averse), begitu juga sebaliknay pembuat keputusan akan memilih pilihan yang berisiko apabila informasi dinyatakan dalam suatu loss domain atau negative frame, Probabilistic Mental Models menunjukkan suatu kepercayaan sesesorang yang berlebihan (overconfidence) dalam pembuatan judgment dan keputusan. Pembuat keputusan memandang dengan cara yang berbeda terhadap masalah yang sama akibat adanya pembingkaian masalah yang berbeda, Fuzzy Trace Theory mengasumsikan pembuat keputusan lebih memilih penyederhanaan dalam penyajian informasi, kecuali pembuat keputusan tidak bisa menyederhanakan pilihan keputusan dalam informasi yang cukup kompleks.

\section{Tingkat Kepuasan}

Kepuasan merupakan suatu wujud atau pengungkapan perasaan terhadap sesuatu yang telah diperoleh yang berupa reaksi kegembiraan atau kesenangan. Kepuasan seseorang berdasarkan kepada kesesuaian ekspektasi seseorang terhadap apa yang ia peroleh, semakin sesuai ekspektasi atau harapan seseoarang terhadap apa yang ia peroleh maka tingkat kepuasan akan semakin tinggi. (Kotler, 2009) menyatakan bahwa persepsi pelanggan atas produk atau jasa yang telah dibeli. Sedangkan disisi lain kepuasan merupakan suatu gambaran tingkat kepuasan seseorang terhadap apa yang telah diperoleh dengan membandingkan kinerja atau hasil yang dirasakan dengan apa yang diharapkan. Berikut beberapa indikator tingkat kepuasan yaitu sebagai berikut: Sistem keluhan dan saran, Pembeli bayangan, Analisis pelanggan beralih, Survei kepuasan pelanggan

\section{Tingkat Kepercayaan}

Tingkat kepercayaan berkaitan dengan jaminan keamanan yang dapat diberikan oleh pihak perusahaan ataupun instansi tertentu terhadap pelanggannya. Dalam hal ini yang termasuk kedalam jaminan keamanan yaitu bagaimana perusahaan atau instansi mampu menjamin keamanan dan kerahasiaan data ataupun informasi dari pelanggan. Menurut (Morgan, 1994), kepercayaan adalah suatu keyakinan seseorang terhadap diri sendiri dalam melakukan sebuah kerjasama dengan orang lain atau mitra yang dipercaya memiliki integritas dan dapat dapat dipercaya. Adapun indikator tingkat kepercayaan menurut (Mukherjee, A. dan Nath, 2003) adalah sebagai berikut: Orientasi Teknologi, Reputasi, Perceived Risk Loyalitas

Loyalitas merupakan perilaku konsumen yang menunjukaan sikap kepuasan dan kepercayaan yang memadai sehingga terjadinya pembelian atau penggunaan yang berulang-ulang. Selain itu konsumen atau pelanggan akan dengan senang hati merekomendasikan barang atau jasa yang dibelinya kepada orang-orang disekitarnya. Loyalitas merupakan suatu ukuran kesetiaan pelanggan untuk menggunakan suatu merek produk atau jasa pada waktu tertentu dalam keadaan banyak pilihan merek produk atau jasa lainnya. Adapun indikator loyalitas adalah sebagai berikut: Repeat Purchase adanya pembelian atau penggunaan yang berulang terhadap suatu produk atau jasa, Retention seorang pelanggan tidak akan terpengaruh terhadap isu negatif terhadap produk atau jasa yang iya gunakan secara rutin dan terus-menerus, Referalls pelanggan akan merekomendasikan produk atau jasa yang ia gunakan terhadap orang-orang disekitarnya.

\section{Hipotesis Penelitian}

$\mathrm{H} 1=$ Customer Relationship Management berpengaruh positif terhadap tingkat kepercayaan nasabah dalam penggunaan layanan Mobile Banking.

$\mathrm{H} 2=$ Customer Relationship Management berpengaruh positif terhadap loyalitas nasabah dalam penggunaan layanan Mobile Banking. 
H3 = Framing Effect berpengaruh positif terhadap tingkat kepercayaan nasabah dalam penggunaan layanan Mobile Banking.

$\mathrm{H} 4$ = Framing Effect berpengaruh positif terhadap loyalitas nasabah dalam penggunaan layanan Mobile Banking.

H5 = Tingkat kepuasan berpengaruh positif terhadap tingkat kepercayaan nasabah dalam penggunaan layanan

\section{METODE PENELITIAN}

\section{Populasi dan Sampel}

Populasi yag akan digunakan dalam penelitian ini adalah nasabah yang menggunakan layanan aplikasi Mobile Banking yaitu sebesar 110.027 pengguna berdasarkan data E-Channel Bank BRI 2018. Sedangkan untuk teknil sampel yang akan digunakan adalah teknik nonprobability sampling yaitu dengan cara accidental sampling atau dengan cara penentuan sampel berdasarkan kebetulan. Penentuan jumlah sampel digunakan rumus slovin yang didapat berdasarkan perhitungan yaitu sebesar 100 responden.

\section{Teknik Pengumpulan Data}

Teknik pengumpulan data yang akan digunakan yaitu dengan cara penyebaran kuesioner dengan skala likert, dengan pemberian pertanyaan atau pernyataan berdasarkan variabel pada penelitian yang diberi nilai dengan skala 5 poin.

\section{Teknik Analisis Data}

Penelitian ini menggunakan teknik Partial Least Squares (PLS) yaitu dengan menggunakan tiga metode, sebagai berikut:

\author{
IV. HASIL PENELITIAN DAN PEMBAHASAN \\ Hasil Analisis PLS \\ 1. Inner Model
}

Mobile Banking.

H6 = Tingkat kepuasan berpengaruh positif terhadap loyalitas nasabah dalam penggunaan layanan Mobile Banking.

H7 = Tingkat kepercayaan nasabah berpengaruh positif terhadap loyalitas nasabah dalam penggunaan layanan Mobile Banking.

1. Model Pengukuran (Outer Model)

Digunakan untuk menguji validitas konstruk dan reliabilitas instrument. Uji validitas digunakan untuk mengetahui kemampuan instrument penelitian, sedangkan uji reliabilitas digunakan untuk mengukur konsistensi alat ukur dalam mengukur suatu konsep.

2. Model Struktural (Inner Model)

Digunakan untuk mendiskripsikan hubungan antar konstruk atau variabel laten.model ini dievaluasi dengan menggunakan $R^{2}$ untuk konstruk dependen, nilai koefisien path atau $t$ values tiap path untuk uji signifikansi antar konstruk dalam model struktural.

3. Uji Hipotesis

Dalam penelitian ini akan ditekankan kepada Hipotesis Kausal yang merupakan dugaan sementara tentang pengaruh antara variabel terhadap variabel lain. Di antara variabel yang saling berhubungan tersebut tampak variabel sebab atau yang mempengaruhi dan variabel akibat atau yang dipengaruhi. 


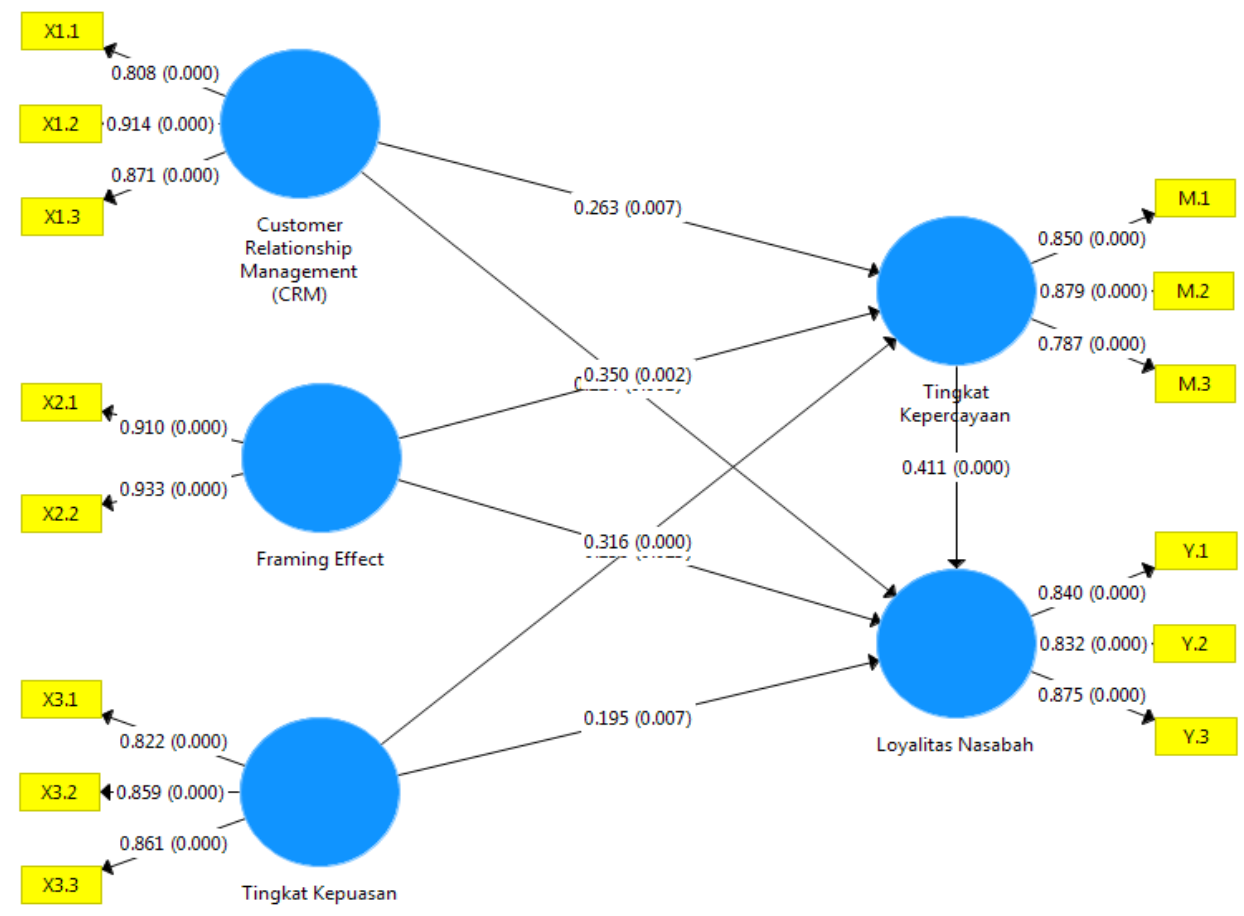

a. $R$-square

\begin{tabular}{|l|r|r|}
\hline & \multicolumn{1}{|c|}{ R Square } & R Square Adjusted \\
\hline Loyalitas Nasabah & 0.842 & 0.835 \\
\hline Tingkat Kepercayaan & 0.689 & 0.680 \\
\hline
\end{tabular}

Pada tabel diatas dapat dilihat bahwa pengaruh Customer Relationship Management, Framing Effect, Tingkat Kepuasan terhadap loyalitas nasabah sebesar $84,2 \%$, dan pengaruh Customer Relationship Management, Framing Effect, Tingkat Kepuasan terhadap tingkat kepercayaan nasabah sebesar $68,9 \%$

$\mathrm{Q}^{2}=1-[(1-0,842)(1-0,689)]$

$\mathrm{Q}^{2}=1-[(0,158)(0,311)]$

$\mathrm{Q}^{2}=1-(0.049)$

$\mathrm{Q}^{2}=0,951$

Berdasarkan perhitungan yang telah b. Q-square $\mathrm{Q}^{2}=1-\left[\left(1-\mathrm{R}_{1}{ }^{2}\right)\left(1-\mathrm{R}_{2}{ }^{2}\right)\right]$ dilakukan diatas, model dalam penelitian ini dapat dikatakan memiliki nilai prediktif yang relevan karena nilai yang dihasilkan yaitu sebesar 0,951 sudah lebih dari nilai 0 (nol).

2. Pengujian Hipotesis

\begin{tabular}{|l|r|r|r|r|r|}
\hline & $\begin{array}{l}\text { Original } \\
\text { Sample } \\
\text { (O) }\end{array}$ & $\begin{array}{l}\text { Sample } \\
\text { Mean } \\
\text { (M) }\end{array}$ & $\begin{array}{l}\text { Standard } \\
\text { Deviation } \\
\text { (STDEV) }\end{array}$ & $\begin{array}{l}\text { T Statistics } \\
\text { (|O/STDEV|) }\end{array}$ & \multicolumn{1}{l|}{ V Values } \\
\hline $\begin{array}{l}\text { Customer Relationship Management } \\
\text { (CRM) -> Loyalitas Nasabah }\end{array}$ & 0.224 & 0.222 & 0.070 & 3.196 & $\mathbf{0 . 0 0 1}$ \\
\hline $\begin{array}{l}\text { Customer Relationship Management } \\
\text { (CRM) -> Tingkat Kepercayaan }\end{array}$ & 0.263 & 0.266 & 0.097 & 2.700 & $\mathbf{0 . 0 0 7}$ \\
\hline Framing Effect -> Loyalitas Nasabah & 0.196 & 0.192 & 0.089 & 2.192 & $\mathbf{0 . 0 2 9}$ \\
\hline $\begin{array}{l}\text { Framing Effect -> Tingkat } \\
\text { Kepercayaan }\end{array}$ & 0.350 & 0.346 & 0.114 & 3.069 & $\mathbf{0 . 0 0 2}$ \\
\hline $\begin{array}{l}\text { Tingkat Kepercayaan -> Loyalitas } \\
\text { Nasabah }\end{array}$ & 0.411 & 0.418 & 0.074 & 5.525 & $\mathbf{0 . 0 0 0}$ \\
\hline
\end{tabular}




\section{Tingkat Kepuasan -> Loyalitas \\ Nasabah \\ Tingkat Kepuasan -> Tingkat \\ Kepercayaan \\ Pembahasan \\ 1. Pengaruh Costumer Relationship Management Terhadap Loyalitas Nasabah \\ Berdasarkan hasil analisis data didapat hasil nilai p-value variabel Costumer Relationship Management terhadap Loyalitas Nasabah sebesar 0,001 yang dibandingkan dengan signifikan sebesar 0,05 . Karena nilai $p$ - value < signifikan $(0,001<0,05)$ dengan nilai beta sebesar positif 0,224 dan nilai $t$ statistics sebesar 3,196 yang dibandingkan dengan t-tabel sebesar 1,96. Karena nilai t-statistics $>\mathrm{t}$-value $(3,196>1,96)$ maka dapat disimpulkan bahwa Costumer Relationship Management berpengaruh positif terhadap Loyalitas Nasabah.}

2. Pengaruh Costumer Relationship Management Terhadap Tingkat Kepercayaan

Berdasarkan hasil analisis data didapat hasil nilai $p$-value variabel Costumer Relationship Management terhadap Tingkat Kepercayaan sebesar 0,007 yang dibandingkan dengan signifikan sebesar 0,05 . Karena nilai $p$ value < signifikan $(0,007<0,05)$ dengan nilai beta sebesar positif 0,263 dan nilai t statistics sebesar 2,700 yang dibandingkan dengan t-tabel sebesar 1,96. Karena nilai t-statistics $>\mathrm{t}$-value $(2,700>1,96)$ maka dapat disimpulkan bahwa Costumer Relationship Management berpengaruh positif terhadap Tingkat Kepercayaan.

3. Pengaruh Framming Effect Terhadap Loyalitas Nasabah

Sesuai dengan hasil analisis data maka didapat hasil yaitu nilai $p$-value variabel Framming Effect terhadap Loyalitas Nasabah sebesar 0,029 yang dibandingkan dengan signifikan sebesar 0,05 . Karena nilai p-value < signifikan $(0,029<0,05)$ dengan nilai beta sebesar positif 0,196 dan nilai t statistics sebesar 2,192 yang dibandingkan dengan t-tabel sebesar 1,96. Karena nilai t-statistics > t-value $(2,192>$ 1,96) maka dapat disimpulkan bahwa Framming Effect berpengaruh positif terhadap Loyalitas Nasabah.

\section{Pengaruh Framming Effect Terhadap Tingkat Kepercayaan}

Hasil analisis data menunjukan bahwa nilai

\begin{tabular}{|l|l|l|l|}
0.193 & 0.072 & 2.729 & $\mathbf{0 . 0 0 7}$ \\
\hline 0.316 & 0.083 & 3.821 & $\mathbf{0 . 0 0 0}$ \\
\hline
\end{tabular}

p-value variabel Framming Effect terhadap Tingkat Kepercayaan sebesar 0,002 yang dibandingkan dengan signifikan sebesar 0,05 . Karena nilai $p$-value < signifikan $(0,002<0,05)$ dengan nilai beta sebesar positif 0,350 dan nilai $t$ statistics sebesar 3,069 yang dibandingkan dengan t-tabel sebesar 1,96. Karena nilai tstatistics > t-value $(3,069>1,96)$ maka dapat disimpulkan bahwa Framming Effect berpengaruh positif terhadap Tingkat Kepercayaan.

\section{Pengaruh Tingkat Kepuasan Terhadap} Loyalitas Nasabah

Berdasarkan hasil analisis data didapat hasil nilai $p$-value variabel Tingkat Kepuasan terhadap Loyalitas Nasabah sebesar 0,007 yang dibandingkan dengan signifikan sebesar 0,05. Karena nilai $p$-value < signifikan $(0,007<0,05)$ dengan nilai beta sebesar positif 0,195 dan nilai $t$ statistics sebesar 2,792 yang dibandingkan dengan t-tabel sebesar 1,96. Karena nilai tstatistics > t-value $(2,792>1,96)$ maka dapat disimpulkan bahwa Tingkat Kepuasan berpengaruh positif terhadap Loyalitas Nasabah.

\section{Pengaruh Tingkat Kepuasan Terhadap Tingkat Kepercayaan}

Hasil analisis data menunjukan bahwa nilai p-value variabel Tingkat Kepuasan terhadap Tingkat Kepercayaan sebesar 0,000 yang dibandingkan dengan signifikan sebesar 0,05 . Karena nilai $p$-value < signifikan $(0,000<0,05)$ dengan nilai beta sebesar positif 0,316 dan nilai $t$ statistics sebesar 3,821 yang dibandingkan dengan t-tabel sebesar 1,96. Karena nilai tstatistics > t-value $(3,821>1,96)$ maka dapat disimpulkan bahwa Tingkat Kepuasan berpengaruh positif terhadap Tingkat Kepercayaan.

\section{Pengaruh Tingkat Kepercayaan Terhadap} Loyalitas Nasabah

Berdasarkan hasil analisis data didapat hasil nilai $p$-value variabel Tingkat Kepercayaan terhadap Loyalitas Nasabah sebesar 0,000 yang dibandingkan dengan signifikan sebesar 0,05 . Karena nilai $p$-value $<$ signifikan $(0,000<0,05)$ dengan nilai beta sebesar positif 0,411 dan nilai $t$ statistics sebesar 5,525 yang dibandingkan 
dengan t-tabel sebesar 1,96. Karena nilai tstatistics > t-value $(5,525>1,96)$ maka dapat

\section{KESIMPULAN DAN SARAN Simpulan}

Berdasarkan hasil analisis data dan pembahasan pada bab sebelumnya, maka dapat ditarik simpulan sebagai berikut:

1. Costumer Relationship Management, Framing Effect, Tingkat Kepuasan berpengaruh positif terhadap Tingkat Kepercayaan dan Loyalitas Nasabah, begitu pula Tingkat Kepercayaan berpengaruh positif terhadap Loyalitas Nasabah dalam penggunaan layanan Mobile Banking pada nasabah bank BRI Cabang Renon.

2. Sesuai hasil penelitian yang telah dijabarkan, Costumer Relationship Management mampu memberikan pengaruh yang positif, melalui CRM muncul sebuah layanan Mobile Banking yang dapat mempengaruhi tingkat kepercayaan dan loyalitas nasabah terhadap bank. Kemudian Framing Effect juga berpengaruh positif terhadap tingkat kepercayaan dan loyalitas nasabah karena bank BRI telah mampu menyampaikan informasi yang memadai terkait layanan Mobile Banking kepada nasabah. Dengan adanya layanan Mobile Banking yang memberikan kemudahan kepada nasabah dan penyampaian informasi yang memadai, nasabahpun merasakan kepuasan terhadap layanan yang diberikan, oleh sebab itu kepuasan berpengaruh positif terhadap tingkat kepercayaan dan loyalitas nasabah. Setelah

\section{DAFTAR PUSTAKA}

Kahneman, D., \& Tversky, A. (1979). Prospect Theory: An

Analysis of Decisions Under Risk. Econometrica, 47(2), 263-291.

Kotler, \& K. (2009). Manajemen Pemasaran (13th ed.). Erlangga.

Marakas, George M. dan O’brien, J. A. (2017). Pengantar Sistem Informasi. Salemba Empat.

Morgan, R. M. dan S. D. H. (1994). The Commitment Trust

Theory of Relationship Marketing. Journal of Marketing.

Vournal of Marketing, 58(3).

Mukherjee, A. dan Nath, P. (2003). A Model of Trust in Online disimpulkan bahwa Tingkat Kepercayaan berpengaruh positif terhadap Loyalitas Nasabah.

nasabah percaya terhadap layanan yang telah diberikan oleh pihak bank, nasabah telah mampu memberikan loyalitas yang tinggi terhadap bank, maka dari itu tingkat kepercayaan dapat dikatakan berpengaruh positif terhadap loyalitas nasabah dalam penggunaan layanan Mobile Banking pada nasabah bank BRI Cabang Renon.

\section{Saran}

1. Bagi mahasiswa, hasil penelitian ini dapat digunakan sebagai sumber ajar atau studi kasus dalam kegiatan pada mata kuliah tertentu. Selain itu, hasil penelitian ini dapat digunakan sebagai kajian pustaka dalam rangka melakukan penelitian sejenis dengan cara menambah sampel penelitian serta merekontruksi model penelitian dengan variabel lain sehingga hasil penelitain sesuai dengan keadaan sebenarnya.

2. Bagi layanan Mobile Banking, hasil penelitian ini dapat digunakan untuk mengoptimalkan Loyalitas Nasabah dalam Penggunaan Layanan Mobile Banking dengan meningkatkan Customer Relationship Management (CRM), Framing Effect, Tingkat Kepuasan dan Tingkat Kepercayaan Nasabah dalam Penggunaan Layanan Mobile Banking.

3. Bagi Universitas, hasil penelitian ini dapat digunakan sebagai materi ajar serta contoh dalam menelaah studi kasus pada mata kuliah tertentu dalam rangka mempersiapkan lulusan yang nantinya berkeinginan meneliti lebih lanjut tentang penggunaan layanan mobile banking.

Relationship Banking. International Journal of Banking.

Robbins SP, dan J. (2011). Perilaku Organisasi. Salemba

Empat.

Sari, R. C. (2018). Akuntansi Keperilakuan. CV Andi.

Sirait, D. P. (2018). PENGARUH CUSTOMER

\section{RELATIONSHIP MANAGEMENTDAN KUALITAS PELAYANAN TERHADAP KEPUASAN}

PELANGGAN ( The Effect of Relationship Management and Service Quality on Customer Satisfaction). Jurnal

Digest Marketing, 3(1), 79-85. 